Article

\title{
New Urbanization, Energy-Intensive Industries Agglomeration and Analysis of Nitrogen Oxides Emissions Reduction Mechanisms
}

\author{
Yang $\mathrm{Yu}$ * and Tianchang Wang
}

Citation: Yu, Y.; Wang, T. New Urbanization, Energy-Intensive Industries Agglomeration and Analysis of Nitrogen Oxides Emissions Reduction Mechanisms. Atmosphere 2021, 12, 1244. https:// doi.org/10.3390/atmos12101244

Academic Editors: Duanyang Liu, Kai Qin and Honglei Wang

Received: 24 August 2021 Accepted: 18 September 2021 Published: 24 September 2021

Publisher's Note: MDPI stays neutral with regard to jurisdictional claims in published maps and institutional affiliations.

Copyright: (c) 2021 by the authors. Licensee MDPI, Basel, Switzerland. This article is an open access article distributed under the terms and conditions of the Creative Commons Attribution (CC BY) license (https:// creativecommons.org/licenses/by/ $4.0 /)$.
School of Economics and Management, Beijing University of Chemical Technology, Beijing 100029, China; 2019200891@mail.buct.edu.cn

* Correspondence: yuyang@mail.buct.edu.cn

\begin{abstract}
With the deepening of urbanization and industrialization, as well as the exacerbation of energy consumption, China is facing a severe situation in which nitrogen oxide (NOx) emissions reduction is imperative. In this study, it is aimed to put forward countermeasures and suggestions to reduce NOx emissions by analyzing the impact and mechanism of new urbanization, the agglomeration of energy-intensive industries and mutual interactions on China's NOx emissions. By analyzing the data of 30 provinces in China from 2006 to 2017, this paper adopted the system generalized method of moments (SYS-GMM) and intermediary effect model to introduce four variables, such as: energy efficiency, human capital, industrial structure and energy structure, which were for empirical analysis. From the results, it was shown that: (1) NOx emissions in China have an accumulated effect; (2) new urbanization inhibits NOx emissions, whilst the agglomeration of energy-intensive industries intensifies NOx emissions. New urbanization weakens the negative impact of the agglomeration of energy-intensive industries on NOx emissions reduction and, (3) among the impacts of new urbanization on NOx emissions, the energy efficiency and human capital reflect the intermediary effect mechanism. At the same time, in the impact of the agglomeration of energy-intensive industries on NOx emissions, the industrial structure and energy structure show the mechanisms of the intermediary effect and masking effect, respectively.
\end{abstract}

Keywords: air pollution; new urbanization; energy-intensive industries agglomeration; NOx emissions; intermediary effect model; transmission mechanism

\section{Introduction}

In the "2030 Agenda for Sustainable Development" formulated by the United Nations, 17 sustainable development goals were put forward; among which, SGD11 and SGD13 describe the requirements for building sustainable cities and solving the problems of climate changes, respectively. A key role has been played by new urbanization in promoting urban and ecological sustainable development. In recent years, China's urban air quality has been continuously improved; despite this, there are still some atmospheric pollutants, such as nitrogen oxides, ozone and other gases, that have been emitted at a high level. The emissions reduction effect of these gases is not obvious and brings huge challenges to the prevention and control of air pollution. Nitrogen oxides $\left(\mathrm{NOx}=\mathrm{NO}+\mathrm{NO}_{2}\right)$ is one of the most serious air pollutants, and its hazards are reflected in environmental governance and human health. NOx not only directly affects the concentration of nitrogen dioxides in the air but is also the main source of ozone pollutants. In the research on how these gasses harm human health, scholars have discussed the adverse effects of NOx on human life expectancy [1], asthma symptoms [2], mental health disorders complicating pregnancy [3,4] and lung function [5] at birth. In 2018, NOx accounting for the highest proportion of total industrial waste gas emissions, seriously hindering the improvement of China's new urbanization level and the construction of ecological civilization. 
In China, NOx emissions are mainly from transportation sources (using automobile engines) and industrial sources (boiler combustion and cement and steel production). It has been pointed out that $75.34 \%$ of the NOx emissions from industrial sources focus on nonmetallic mineral products, electric power, thermal power production and supply and ferrous metal smelting and rolling processing industries in energy-intensive industries (Bulletin of the second national survey of pollution sources [6]). It is necessary to reduce NOx emissions from the source, which means that the structure of energy-intensive industries should be upgraded. At present, the view that it is significant to adjust the industrial spatial layout by means of industrial agglomeration give full attention to the technology spillover effect and improve the environment has been recognized by most scholars [7-10]. During the process of actively promoting new urban construction in China, the profound changes are dramatic in the industrial layout. However, it remains to be explored whether the geographical concentration of energy-intensive industries will reduce pollutant emissions. Therefore, it has important guidelines for furthering the construction of new urbanization, optimizing the industrial layout and reducing NOx emissions to clarify the impact and mechanism of new urbanization and energy-intensive industry agglomerations on $\mathrm{NOx}$ emissions in China.

It is an important guarantee for sustainable social development to make the development of urbanization and the environment harmonious. The relationship between them has been widely explored by scholars. It is concluded from the research on this topic covering: urbanization improving environmental pollution [11,12], urbanization intensifying environmental pollution $[13,14]$ and the nonlinear relationship between urbanization and environmental pollution [15-17]. Based on a nonlinear relationship, in the early stages of urbanization, with the level of urbanization increasing, pollution intensifies. After that, when urbanization reaches a certain level, pollution will be improved. In some scholars' opinions, they attribute the impact of urbanization on the environment to population growth and industrial agglomeration, holding the opinion that population growth and industrial agglomeration brought about by urbanization have a greater impact on the environment. From the perspective of population factors, as early as 1978, Malthus pointed out that a lack of technology and that population growth will reach the limit because of resource shortage; at the same time, the impact of demographic factors on the environment is also universal [18]. Since then, from the research, large number of scholars have also believed the negative impact of population growth on the environment [19-22].

From the perspective of agglomeration, with the development of urbanization, industrial agglomeration is a form of enterprise agglomeration of organizations with close geographical locations and industrial connections. Some scholars believe that industrial agglomeration has a positive effect on the improvement of environmental pollution. First, most industries gather in specific areas based on unique regional resource conditions, thereby reducing transboundary pollution [23]. Second, industrial agglomeration will attract a large amount of labor force. Meanwhile, specialized equipment can be applied on a large scale, thus promoting the development of specialized investments and services [24]. Third, industrial agglomeration will benefit mutual learning among enterprises and promote the spillover of knowledge and technology $[10,25]$. In contrast, other scholars believe that industrial agglomeration has exacerbated environmental pollution [26-28], expanding the production scale and output $[29,30]$ and causing crowding effects, as well as environmental damage. Furthermore, other scholars have also verified the nonlinear relationship between industrial agglomeration and environmental pollution [31-33].

NOx is a kind of air pollutant, and manmade NOx emissions mainly come from energy consumption. Considering the seriousness of NOx emissions, large number of scholars have confirmed energy-intensive industries such as iron and steel [34], thermal power [35], cement [36,37] and petrochemicals [38] have bad influences on NOx emissions. After subdividing these industrial sectors, scholars proposed that the emission factors of power generation in the iron and steel industry should be reduced [39], and coal-fired 
power plants should implement ultra-low emissions policies [35], strengthen technology research and development [40] and reduce NOx emissions.

By analyzing the literature, it was found as below: firstly, although scholars have conducted deep research into the relationships between urbanization and environmental pollution, industrial agglomeration and environmental pollution, their conclusions are not confirmed. Secondly, the existing literature has covered few researches on the action path of urbanization and industrial agglomeration on the environment, as well as the pollutants rarely involving NOx. Thirdly, with the new urbanization being promoted, the industry has been modified in the original spatial layout; however, few scholars have researched and discussed the relationship between energy-intensive industries and nitrogen oxides from the perspective of agglomeration.

Recently, scholars have paid more attention to evaluating the ecological efficiency [41-44] during the period of measuring the level of urbanization. A new urbanization index system will be constructed, including four dimensions such as population, social development, ecological environment and land, integrating the new urbanization and agglomeration of energy-intensive industries into a unified framework and analyzing their impact on China's NOx emissions by applying the systematic GMM method. In addition, this paper also applied the intermediary effect model to explore the action path of new urbanization and agglomeration of energy-intensive industries on NOx emissions. Finally, some suggestions are put forward to reduce the NOx emissions, in order to provide countermeasures to deal with the air pollution problems during development.

\section{Methodology}

\subsection{Model Setting}

\subsubsection{Benchmark Regression Model}

Liu et al. [28] investigated the relationship between industrial agglomeration and environmental pollution by adding industrial agglomeration into the production function. Zhu and Yan [45] extended the model on this basis and introduced urbanization into the equation. Based on the theories and methods of Zhu and Yan [45], in this paper, a regression equation was constructed, including new urbanization (nurb), the agglomeration of energy-intensive industries (hagg) and NOx emissions (NE). Based on previous studies [46-50], this paper introduced five control variables, such as the industrial structure (is), technological innovation $(r \& d)$, foreign direct investment (fdi), environmental regulation (er) and economic development ( $p g d p)$. In order to avoid heteroscedasticity, all variables were treated with a logarithm, and the benchmark regression model was set as below:

$$
\begin{gathered}
\ln N E_{i t}=\beta+\beta_{1} \ln n u r b_{i t}+\beta_{2} \ln h a g g_{i t}+\beta_{3} \ln i s_{i t}+\beta_{4} \ln r \& d_{i t}+\beta_{5} \ln f d i_{i t} \\
+\beta_{6} \ln e r_{i t}+\beta_{7} \ln p g d p_{i t}+\varepsilon_{i t}
\end{gathered}
$$

In Equation (1) and the following equations, $\varepsilon_{i t}$ is the standard error term.

The new urbanization and agglomeration of energy-intensive industries interact with each other. At the same time, considering a certain dynamic lag of NOx emissions, the interaction term between the new urbanization and agglomeration of energy-intensive industries and the first-order lag term of NOx emissions were introduced to build a dynamic model as follows:

$$
\begin{aligned}
\ln N E_{i t} & =\eta+\eta_{0} \ln N E_{i, t-1}+\eta_{1} \ln n u r b_{i t}+\eta_{2} \ln h a g g_{i t}+\eta_{3} c \ln n u r b_{i t} * c \ln h a g g_{i t} \\
& +\eta_{4} \ln i s_{i t}+\eta_{5} \ln r \& d_{i t}+\eta_{6} \ln f d i_{i t}+\eta_{7} \ln e_{i t}+\eta_{8} \ln p g d p_{i t}+\varepsilon_{i t}
\end{aligned}
$$

Among them, thanks to the variable centralization, the multicollinearity problem caused by the introduction of interaction terms can be avoided effectively. $c \ln n u r b_{i t}$ and $c \ln h a g g_{i t}$ are the variable representations after being intensively processed.

It makes the model having a dynamic interpretation ability to introduce the first-order lag term of NOx emissions into the regression model, but it will result in endogenous problems of the model. The different generalized methods of moments (DIF-GMM) can 
reduce the influence of endogeneity on the model estimation. However, the DIF-GMM has serious problems, such as: weak instrumental variables and poor accuracy of the coefficient estimation results. From this, scholars combined the horizontal equation and the first-order difference equation, as well as proposed the system generalized method of moments (SYS-GMM) [51,52]. Due to limited samples, the system GMM method ensures the accuracy of the estimation. Therefore, Stata 16.0 [53] was used to analyze the model based on the system generalized moment estimation method.

\subsubsection{Intermediary Effect Model}

To explore the transmission mechanism of new urbanization and energy-intensive industry agglomeration to nitrogen oxides, this paper constructed an intermediary effect model by referring to the method of a stepwise testing regression coefficient proposed by Judd and Kenny [54] and Baron and Kenny [55]:

$$
\begin{gathered}
\ln N E_{i t}=\theta+\theta_{0} \ln N E_{i, t-1}+\theta_{1} \ln X_{i t}+\theta_{2} \ln \pi_{i t}+\varepsilon_{i t} \\
\ln M_{i t}=\omega+\omega_{0} \ln M_{i, t-1}+\omega_{1} \ln X_{i t}+\omega_{2} \ln \pi_{i t}+\varepsilon_{i t} \\
\ln N E_{i t}=\rho+\rho_{0} \ln N E_{i, t-1}+\rho_{1} \ln X_{i t}+\rho_{2} \ln M_{i t}+\rho_{3} \ln \pi_{i t}+\varepsilon_{i t}
\end{gathered}
$$

In the process of replacing $X$ in the equation with nurb, $M$ is regressed with energy efficiency (ee) and human capital $(h c)$, respectively. In the process of replacing $\mathrm{X}$ in the equation with hagg, $\mathrm{M}$ is regressed with the industrial structure (is) and energy structure (es), respectively.

Based on the intermediary effect model: (1) if the total effect coefficient $\theta_{1}$ is significant, it should be the intermediary effect; otherwise, it is the masking effect. (2) If the coefficients $\omega_{1}$ and $\rho_{2}$ are significant, the indirect effect of $\omega_{1} \times \rho_{2}$ is significant. (3) If the coefficient $\rho_{1}$ of the direct effect is significant, $\omega_{1} \times \rho_{2}$ and $\rho_{1}$ are the same sign, which reflects the intermediary effect, and if $\omega_{1} \times \rho_{2}$ and $\rho_{1}$ are different signs, it reflects the masking effect $[56,57]$. In addition, the mediating effect should satisfy that the coefficient $\rho_{1}$ is less than the coefficient $\theta_{1}$.

\subsection{Index Construction}

\subsubsection{New Urbanization}

Compared with the traditional urbanization measured only by the indicator of population, as for the new urbanization, more attention should be attached to the quality of urban development. From this, referring to the existing research [58-61], this paper constructed a new comprehensive evaluation index system of the urbanization level from 13 indexes and four aspects, including population, social development, ecological environment and land, which are shown in Table 1.

Based on the variation degree of each index, the entropy method determines the index weight, and the evaluation deviation of the human factors is avoided to a certain extent. In this paper, the entropy method is applied to measure the weight for each index in the new urbanization index system. The calculation formula of the weight is as follows:

Step 1: Calculate the proportion of index $j$ :

$$
y_{i j}=\frac{X_{i j}}{\sum_{i=1}^{n} X_{i j}}, i=1,2, \ldots, n, j=1,2, \ldots, m
$$

Step 2: Calculate the entropy of index $j$ :

$$
e_{j}=-\frac{1}{\ln n} \sum_{i=1}^{n} y_{i j} \ln y_{i j}
$$


Step 3: Calculate the weight of each indicator:

$$
\omega_{j}=\frac{\left(1-e_{j}\right)}{\sum_{j=1}^{m}\left(1-e_{j}\right)}
$$

$X_{i j}$ is the result of the standardization of the actual value of the $j$ th index in the $i$ th province, $Y_{i j}$ is the proportion of the actual value of the $j$ th index in the $i$ th province, $e_{j}$ is the information entropy of the index and $\omega_{j}$ is the entropy weight. Table 1 lists the comprehensive evaluation index system of the new urbanization level.

Table 1. The comprehensive evaluation index system of the new urbanization levels.

\begin{tabular}{|c|c|c|c|}
\hline Target Layer & Dimension & Index & Polarity \\
\hline \multirow{13}{*}{$\begin{array}{c}\text { Comprehensive } \\
\text { evaluation index } \\
\text { of new urbanization }\end{array}$} & \multirow{3}{*}{ Population urbanization } & Proportion of urban population (\%) & + \\
\hline & & Urban population density (people $/ \mathrm{km}^{2}$ ) & + \\
\hline & & Dependency ratio of the elderly population (\%) & + \\
\hline & \multirow{3}{*}{$\begin{array}{c}\text { Social development } \\
\text { urbanization }\end{array}$} & Medical insurance (ten thousand) & + \\
\hline & & Proportion of fixed assets investment (\%) & + \\
\hline & & $\begin{array}{c}\text { Consumption proportion of urban and rural } \\
\text { residents (\%) }\end{array}$ & - \\
\hline & \multirow{5}{*}{$\begin{array}{c}\text { Ecological environment } \\
\text { urbanization }\end{array}$} & Number of museums (unit) & + \\
\hline & & Pollution-free treatment rate of domestic waste $(\%)$ & + \\
\hline & & Per capita green space $\left(\mathrm{m}^{2} /\right.$ person $)$ & + \\
\hline & & Urban green space area (hectares) & + \\
\hline & & Number of parks (unit) & + \\
\hline & \multirow{2}{*}{ Land urbanization } & Per capita urban road area $\left(\mathrm{m}^{2}\right)$ & + \\
\hline & & Construction area $\left(\mathrm{km}^{2}\right)$ & + \\
\hline
\end{tabular}

\subsubsection{Energy-Intensive Industries Agglomeration}

This paper measures the degree of industrial agglomeration by the number of employees in six energy-intensive industries (chemical raw materials and chemical products manufacturing industry, nonmetallic mineral manufacturing industry, ferrous metal smelting and rolling processing industry, nonferrous metal smelting and rolling processing industry, petroleum processing coking and nuclear fuel processing industry, and power and heat production and supply industry). The calculation formula is as follows:

$$
\operatorname{hagg}_{i j}=\frac{\left(m_{i j} / m_{j}\right)}{\left(M_{i} / M\right)}
$$

where $m_{i j}$ is the employment of industry $i$ in area $j, m_{j}$ is the employment of all the industries in area $j, M_{i}$ is the national employment of industry $i$ and $M$ is the employment number of all the industries in the country.

\subsection{Data Description}

Considering the availability of the data, this paper selected the panel data of 30 provinces in China (excluding Tibet, Hong Kong, Macao and Taiwan) from 2006 to 2017 to verify the relationship between new urbanization, energy-intensive industries agglomeration and NOx emissions and the intermediary effect. The data comes from the China Statistical Yearbook (2007-2018) [62] and China Environment Yearbook (2007-2018) [63,64]. The GDP data used in the variables were calculated at a constant price in 2006 and were processed by using a logarithm. The representation and descriptive statistics of the related variables are shown in Table 2. 
Table 2. Variable description statistics.

\begin{tabular}{|c|c|c|c|c|c|}
\hline Variables & Representations of Variable & Mean & Std. Dev. & Min. & Max. \\
\hline $\ln N E$ & Regional NOx emissions & 3.8538 & 0.7655 & 1.3863 & 5.1936 \\
\hline $\ln n u r b$ & - & 5.8389 & 0.4071 & 4.4776 & 6.7733 \\
\hline $\operatorname{lnhagg}$ & - & 0.0691 & 0.4509 & -1.2463 & 1.6868 \\
\hline $\ln p g d p$ & GDP per resident population & 10.3004 & 0.6220 & 8.6570 & 11.9360 \\
\hline $\ln e r$ & $\begin{array}{c}\text { Proportion of environmental protection expenditure in fiscal } \\
\text { expenditure in the year }\end{array}$ & -3.5628 & 0.3617 & -4.7732 & -2.6992 \\
\hline $\ln r \& d$ & $\begin{array}{l}\text { The proportion of regional research and experiment funds in } \\
\text { GDP }\end{array}$ & -4.7267 & 0.6613 & -8.0286 & -3.5696 \\
\hline $\ln f d i$ & $\begin{array}{l}\text { The proportion of actual foreign direct investment in industrial } \\
\text { added value of the year }\end{array}$ & 14.4673 & 1.5769 & 9.7361 & 16.9303 \\
\hline $\ln i s$ & The proportion of added value of secondary industry in GDP & -0.6907 & 0.1903 & -1.4451 & -0.4897 \\
\hline $\ln e e$ & $\begin{array}{l}\text { The ratio of gross regional product to regional energy } \\
\text { consumption }\end{array}$ & -0.0643 & 0.4942 & -1.3816 & 1.0164 \\
\hline $\ln h c$ & $\begin{array}{l}\text { The proportion of the number of students in colleges and } \\
\text { universities in the total population of the region }\end{array}$ & 4.092 & 0.8314 & 1.2809 & 5.3059 \\
\hline $\ln e s$ & The ratio of coal consumption to total energy consumption & -0.4733 & 0.4439 & -3.0136 & 0.4248 \\
\hline
\end{tabular}

\section{Results}

\subsection{Stationary Test and Multicollinearity Test of Variables}

Before regression, it is required to test the stationarity of the data to avoid pseudo regression. The unit root test is a common method to test the stationarity of data. For example, Levin, Lin and Chu [65] derived the unit root test (LLC test) from Levin and Lin [66], and it was proposed by IM, Pesaran and Shin [67] that the unit root test considers panel heterogeneity (IPS test). The test results are shown in Table 3. In the LLC test, all the variables deny the original hypothesis of the "existence of a unit root" at the level of $1 \%$, while, in the test of IPS, the variables such as $\ln N E, \ln p g d p, \ln r \& d, \ln i s, \ln e e$ and $\ln h c$ were unstable. After the first-order difference, all the variables rejected the original hypothesis of the "existence of a unit root" at the level of 1\%. At the same time, multicollinearity will distort the regression estimation model. The value of the variance inflation factor (VIF) was calculated to judge whether there was multicollinearity between the prediction variables or not. It was found that the VIF values were less than 10. Therefore, from this, it could be seen that there was no multicollinearity among the variables to ensure the effectiveness of the following regression estimation results.

Table 3. Unit roots and multicollinearity test.

\begin{tabular}{ccccc}
\hline \multirow{2}{*}{ Variables } & \multicolumn{2}{c}{ I (0) } & I (1) & VIF \\
\cline { 2 - 4 } & LLC Test & IPS Test & IPS Test & - \\
\hline $\ln N E$ & $-9.7787^{* * *}$ & -2.1377 & $-9.3706^{* * *}$ & 1.51 \\
$\ln n u r b$ & $-28.3692^{* * *}$ & $-4.7110^{* * *}$ & $-12.5630^{* * *}$ & 2.30 \\
$\ln h a g g$ & $-9.1874^{* * *}$ & $-1.5977^{*}$ & $-8.2932^{* * *}$ & 3.67 \\
$\ln p g d p$ & $-5.4468^{* * *}$ & $1.7051^{* * *}$ & $-4.3022^{* * *}$ & 1.23 \\
$\ln e r$ & $-11.3619^{* * *}$ & $-3.9842^{* * *}$ & $-8.6963^{* * *}$ & 3.00 \\
$\ln r \& d$ & $-5.6201^{* * *}$ & 0.3098 & $-12.3932^{* * *}$ & 4.84 \\
$\ln f d i$ & $-9.6044^{* * *}$ & $-2.7313^{* * *}$ & $-9.0860^{* * *}$ & 2.33 \\
$\ln i s$ & $-7.3855^{* * *}$ & 1.7466 & $-6.4407^{* * *}$ & 5.71 \\
$\ln e e$ & $-3.3887^{* * *}$ & 2.0213 & $-5.4591^{* * *}$ & 4.65 \\
$\ln h c$ & $-5.6826^{* * *}$ & 1.0969 & $-7.6319^{* * *}$ & $-5.4591^{* * *}$ \\
$\ln e s$ & $-9.1010^{* * *}$ & $-1.8949^{* *}$ & -34 \\
\hline
\end{tabular}

Note: ${ }^{*}{ }^{* *}$ and ${ }^{* * *}$ indicate significance at the levels of $10 \%, 5 \%$ and $1 \%$.

\subsection{Regression of the Basic Model}

Considering the robustness of the estimation results, this paper adopted the random effects model, fixed effects model and SYS-GMM model for estimation. From the regression 
results in Columns 1-3, in Table 4, in addition to the estimated coefficient of $\ln f d i$, the influence coefficients of the dependent variables estimated by the random effects model, fixed effects model and SYS-GMM model on NOx emissions were consistent; that is, the robustness of the estimated results was verified. In the estimation of the SYS-GMM method, based on the research of Arellano and Bond [51] and Arellano and Bover [68], the Sargan test and Arellano bond test were applied to determine whether there was a second-order autocorrelation between the effectiveness of the instrumental variables and the error term or not. From the regression results in Table 4, it was shown that, in the Sargan test, the original hypothesis of the effectiveness of the instrumental variables was accepted, and in the statistics of AR (2) in Arellano bond test, the original assumption that the second-order sequence of residual terms had no autocorrelation showed that the model setting was effective.

Table 4. Baseline regression results.

\begin{tabular}{|c|c|c|c|c|}
\hline \multirow{2}{*}{ Variables } & \multicolumn{3}{|c|}{ Contains No Interaction Term } & \multirow{2}{*}{$\begin{array}{c}\text { Contain Interaction Items } \\
\text { SYS-GMM }\end{array}$} \\
\hline & RE & FE & SYS-GMM & \\
\hline \multirow{2}{*}{$\ln N E_{\mathrm{i}, \mathrm{t}-1}$} & - & - & $0.4075^{* * *}$ & $0.4633^{* * *}$ \\
\hline & - & - & $(0.0176)$ & $(0.0242)$ \\
\hline \multirow{2}{*}{$\ln n u r b$} & $-0.1273 *$ & $-0.1750 * *$ & $-0.4766^{* * *}$ & $-0.2929^{* * *}$ \\
\hline & $(0.0773)$ & $(0.0799)$ & $(0.0639)$ & $(0.0992)$ \\
\hline \multirow{2}{*}{$\ln h a g g$} & $0.1723^{* * *}$ & $0.2006^{* * *}$ & $0.1290^{* * *}$ & $0.0963^{* * *}$ \\
\hline & $(0.0631)$ & $(0.0634)$ & $(0.0157)$ & $(0.0167)$ \\
\hline \multirow{2}{*}{ Clnnurb* clnhagg } & - & - & - & $-0.2818^{* * *}$ \\
\hline & - & - & - & $(0.0665)$ \\
\hline \multirow{2}{*}{$\ln i s$} & $2.5061^{* * *}$ & $2.8958^{* * *}$ & $2.1128^{* * *}$ & $1.6204^{* * *}$ \\
\hline & $(0.2845)$ & $(0.3243)$ & $(0.2156)$ & $(0.3252)$ \\
\hline \multirow{2}{*}{$\ln f d i$} & 0.0361 & -0.0040 & $0.1421^{* * *}$ & $0.1173^{* * *}$ \\
\hline & $(0.0321)$ & $(0.0340)$ & $(0.0255)$ & $(0.0199)$ \\
\hline \multirow{2}{*}{$\ln e r$} & $-0.1881^{* * *}$ & $-0.1486^{* *}$ & $-0.4251^{* * *}$ & $-0.3833^{* * *}$ \\
\hline & $(0.0592)$ & $(0.0608)$ & $(0.0372)$ & $(0.0350)$ \\
\hline \multirow{2}{*}{$\ln p g d p$} & $-0.3390^{* * *}$ & $-0.3235^{* * *}$ & $-0.6537^{* * *}$ & $-0.5941^{* * *}$ \\
\hline & $(0.0719)$ & $(0.0768)$ & $(0.0377)$ & $(0.0638)$ \\
\hline \multirow{2}{*}{$\ln r \& d$} & $0.2245^{* * *}$ & $0.2060 * * *$ & $0.4274^{* * *}$ & $0.3560 * * *$ \\
\hline & $(0.0622)$ & $(0.0630)$ & $(0.0463)$ & $(0.0736)$ \\
\hline \multirow{2}{*}{ cons } & $9.6767^{* * *}$ & $10.6965^{* * *}$ & $11.6863^{* * *}$ & $9.6132^{* * *}$ \\
\hline & $(0.9698)$ & (1.0116) & $(0.7497)$ & $(0.9050)$ \\
\hline \multirow{2}{*}{$\operatorname{AR}(1)$} & - & - & -1.8979 & -2.0145 \\
\hline & - & - & $(0.0577)$ & $(0.0440)$ \\
\hline \multirow{2}{*}{$\mathrm{AR}(2)$} & - & - & 1.0735 & 1.074 \\
\hline & - & - & $(0.2830)$ & $(0.2828)$ \\
\hline \multirow{2}{*}{ sargan } & - & - & 28.2426 & 27.6578 \\
\hline & - & - & (1.0000) & $(1.0000)$ \\
\hline
\end{tabular}

Note: ${ }^{*}, * *$ and ${ }^{* * *}$ indicate significance at the levels of $10 \%, 5 \%$ and $1 \%$, respectively; the values in parentheses for the variable and constant items represent the standard errors.

The regression coefficients in all the independent variables wee significant at the $1 \%$ level, and the first-order coefficient in the early stage of the NOx emissions was positive; from this, it was indicated that China's NOx emissions had a cumulative effect, which means the increase of NOx emissions in the early stage will result in the increase of NOx emissions during the current period.

New urbanization, environmental regulation and economic development will promote to reduce NOx emissions. For every $1 \%$ increase in the level of new urbanization, the nitrogen oxides emissions can be reduced by $0.4766 \%$, as, for every $1 \%$ increase in the environmental regulations, the NOx emissions will be reduced by $0.4251 \%$. For every $1 \%$ increase in economic development, nitrogen oxides emissions will be reduced by $0.6537 \%$.

The agglomeration of energy-intensive industries, industrial structure, technological innovation and foreign direct investment were positively correlated with the increase of 
NOx emissions. For every $1 \%$ increase in the agglomeration of energy-intensive industries, NOx emissions will be increased by $0.1290 \%$. The industrial structure is the biggest factor affecting NOx emissions, with the elasticity coefficient reaching 2.1128. Therefore, it is the key to realizing China's NOx emissions reduction to optimize the industrial structure. The elastic coefficient of technological innovation is 0.4274 , which indicates that there is a positive correlation between technological innovation and NOx emissions. From this result, it is shown that China's technological innovation has not yet played its role in reducing emissions $[69,70]$. The coefficient of foreign direct investment is 0.1421 , indicating that, for every $1 \%$ increase in foreign direct investment, the NOx emissions will increase by $0.1421 \%$.

Furthermore, new urbanization will attract similar industries to gather in specific regions, and industrial agglomeration will drive population agglomeration, thereby promoting the development of new urbanization. Therefore, there may be an interaction between the new urbanization and agglomeration of energy-intensive industries. From the regression results in Column 4 in Table 4, it is shown that the new urbanization and agglomeration of energy-intensive industries mutually interact. After adding the interaction terms of the new urbanization and agglomeration of energy-intensive industries, the positive and negative affecting coefficients in each dependent variable on NOx emissions have not been changed and are significant at the level of $1 \%$, which, once again, verifies the robustness of the regression results. The interaction coefficient between the new urbanization and agglomeration of energy-intensive industries is -0.2818 , showing that the promotion of NOx emissions by the agglomeration of high-energy-consuming industries decreases as the level of new urbanization increases. With the improvement development of new urbanization, the adverse impact of energy-intensive industries agglomeration on NOx emissions reduction will be weakened gradually.

\subsection{Mechanism Analysis}

Based on the benchmark study in Table 4, it is found that China's new urbanization has a strong inhibitory effect on NOx emissions; however, energy-intensive industries agglomeration has a strong promotion effect on NOx emissions. In this section, the transmission mechanism of new urbanization and energy-intensive industries agglomeration on NOx emissions is explored with the intermediary effect model.

During the period of exploring the transmission mechanism between new urbanization and NOx emissions, it should be considered whether new urbanization can affect NOx emissions with energy efficiency and human capital. It can be seen from Table 5 that, when energy efficiency was taken as the intermediary variable into the model, the absolute value of the estimated coefficient of the impact of new urbanization on NOx emissions in Equation (5) was less than Equation (3), the impact of new urbanization on the energy efficiency was positive and the impact of the energy efficiency on NOx was negative, which was significant at the level of $1 \%$. At the same time, it showed that energy efficiency is the intermediary variable of new urbanization affecting NOx emissions. New urbanization will benefit the improvement of energy efficiency, which not only reduces the level of unit energy consumption but also produces additional economic benefits, leading to reduce NOx emissions. Therefore, new urbanization reduces NOx emissions by improving the energy efficiency. When human capital is introduced into the model as an intermediary variable, the estimation coefficient of new urbanization on NOx emissions in Equation (5) was less than Equation (3), the impact of new urbanization on human capital was positive and the impact of human capital on NOx was negative. It is shown that human capital is the intermediary variable of the new urbanization affecting NOx emissions. With the improvement of new urbanization, better educational opportunities will be provided for more people, in order to promote human capital. At the same time, as the human capital level improves, it contributes to the enhancement of residents' awareness of environmental protection, playing a positive role in pollutant emissions reduction [71,72], which means that the human capital in new urbanization will improve the reduction of NOx emissions. 
Table 5. Research results on the mechanism of NOx emissions by new urbanization.

\begin{tabular}{|c|c|c|c|c|c|c|}
\hline \multirow{3}{*}{ Variables } & \multicolumn{3}{|c|}{ The Mediating Variable of Energy Efficiency } & \multicolumn{3}{|c|}{ The Mediating Variable of Human Capital } \\
\hline & $\operatorname{lnNE}$ & lnee & $\operatorname{lnNE}$ & $\operatorname{lnNE}$ & $\operatorname{lnhc}$ & $\operatorname{lnNE}$ \\
\hline & (3) & (4) & (5) & (3) & (4) & (5) \\
\hline \multirow{2}{*}{$\ln N E_{\mathrm{i}, \mathrm{t}-1}$} & $0.4238^{* * *}$ & - & $0.4047^{* * *}$ & $0.4238^{* * *}$ & - & $0.4259 * * *$ \\
\hline & $(0.0163)$ & - & $(0.0232)$ & $(0.0163)$ & - & $(0.0296)$ \\
\hline \multirow{2}{*}{$\ln e e_{\mathrm{i}, \mathrm{t}-1}$} & - & $0.8671^{* * *}$ & - & - & - & - \\
\hline & - & $(0.0132)$ & - & - & - & - \\
\hline \multirow{2}{*}{$\ln h c_{\mathrm{i}, \mathrm{t}-1}$} & - & - & - & - & $0.9659 * * *$ & - \\
\hline & - & - & - & - & $(0.0214)$ & - \\
\hline \multirow{2}{*}{$\ln n u r b$} & $-0.4236^{* * *}$ & $0.0470^{* * *}$ & $-0.2199 * * *$ & $-0.4236^{* * *}$ & $0.0089 *$ & $-0.3304^{* * *}$ \\
\hline & $(0.0426)$ & $(0.0076)$ & $(0.0489)$ & $(0.0426)$ & $(0.0048)$ & $(0.0472)$ \\
\hline \multirow{2}{*}{$\ln e e$} & - & - & $-0.9432^{* * *}$ & - & - & - \\
\hline & - & - & $(0.0785)$ & - & - & - \\
\hline \multirow{2}{*}{$\ln h c$} & - & - & - & - & - & $-0.3117^{* * *}$ \\
\hline & - & - & - & - & - & $(0.0957)$ \\
\hline \multirow{2}{*}{$\ln p g d p$} & $-0.6330^{* * *}$ & 0.0361 * & $-0.2535^{* * *}$ & $-0.6330^{* * *}$ & $-0.0330^{* * *}$ & $-0.6642^{* * *}$ \\
\hline & $\begin{array}{c}(0.0351) \\
-0.3980 * * *\end{array}$ & $\begin{array}{c}(0.0201) \\
0.0248^{* * *}\end{array}$ & $\begin{array}{c}(0.0791) \\
-0.3486 * * *\end{array}$ & $\begin{array}{c}(0.0351) \\
-0.3980^{* * *}\end{array}$ & $\begin{array}{c}(0.0078) \\
0.0225 * * *\end{array}$ & $\begin{array}{c}(0.0574) \\
-03433 * * *\end{array}$ \\
\hline $\ln e r$ & $(0.0360)$ & $\begin{array}{l}0.0 \angle 48 \\
(0.0055)\end{array}$ & $\begin{array}{c}-0.3480 \\
(0.0308)\end{array}$ & $\begin{array}{r}-0.3900 \\
(0.0360)\end{array}$ & $(0.0027)$ & $(0.0381)$ \\
\hline \multirow{2}{*}{$\ln r \& d$} & $0.4067^{* * *}$ & -0.0022 & $0.4190 * * *$ & $0.4067^{* * *}$ & $-0.0513^{* * *}$ & $0.4051^{* * *}$ \\
\hline & $(0.0419)$ & $(0.0111)$ & $(0.0444)$ & $(0.0419)$ & $(0.0071)$ & $(0.0360)$ \\
\hline \multirow{2}{*}{$\ln f d i$} & $0.1307^{* * *}$ & $0.0300^{* * *}$ & $0.2554^{* * *}$ & $0.1307^{* * *}$ & $0.0133^{* * *}$ & $0.2363^{* * *}$ \\
\hline & $(0.0231)$ & $(0.0043)$ & $(0.0277)$ & $(0.0231)$ & $(0.0021)$ & $(0.0368)$ \\
\hline \multirow{2}{*}{$\ln i s$} & $2.2238^{* * *}$ & 0.1023 & $1.7462 * * *$ & $2.2238^{* * *}$ & $0.1179^{* * *}$ & $2.5879 * * *$ \\
\hline & $(0.1920)$ & $(0.0645)$ & $(0.2563)$ & $(0.1920)$ & $(0.0287)$ & $(0.3300)$ \\
\hline \multirow{2}{*}{ Cons } & $11.3629 * * *$ & $-0.8930^{* * *}$ & $4.3882 * * *$ & $11.3629 * * *$ & $0.2036^{* *}$ & $11.3177^{* * *}$ \\
\hline & $(0.5210)$ & $(0.2597)$ & $(1.1342)$ & $(0.5210)$ & $(0.0950)$ & $(0.9964)$ \\
\hline \multirow{2}{*}{$\mathrm{AR}(1)$} & -1.8648 & -3.8826 & -2.0264 & -1.8648 & -1.9778 & -1.8819 \\
\hline & $(0.0622)$ & $(0.0001)$ & $(0.0427)$ & $(0.0622)$ & $(0.0479)$ & $(0.0599)$ \\
\hline \multirow{2}{*}{$\mathrm{AR}(2)$} & 0.6226 & 1.4088 & 0.6659 & 0.6226 & 0.3007 & 0.5858 \\
\hline & $(0.5336)$ & $(0.1589)$ & $(0.5055)$ & $(0.5336)$ & $(0.7636)$ & $(0.5580)$ \\
\hline \multirow{2}{*}{ sargan } & 28.9093 & 28.2143 & 28.7847 & 28.9093 & 24.1725 & 28.1055 \\
\hline & (1.0000) & (1.0000) & (1.0000) & (1.0000) & (1.0000) & (1.0000) \\
\hline
\end{tabular}

Note: * ** and ${ }^{* * *}$ indicate significance at the levels of $10 \%, 5 \%$ and $1 \%$, respectively; the values in parentheses for the variable and constant items represent the standard errors.

In the process of exploring the transmission mechanism between the agglomeration of energy-intensive industries and NOx emissions, it should be considered whether energyintensive industries agglomerations can affect NOx emissions with the industrial structure and energy structure. It can be seen from Table 6 that, when the industrial structure is taken as the intermediary variable into the model, the estimation coefficient of the agglomeration of energy-intensive industries on NOx emissions was positive, and Equation (5) was less than Equation (3). The impact of agglomeration of energy-intensive industries on the industrial structure was positive, and the impact of the industrial structure on NOx was positive, which were significant at the confidence level of $1 \%$. At the same time, it also showed that the industrial structure is an intermediary variable for the agglomeration of energy-intensive industries agglomeration to affect NOx emissions. The agglomeration of energy-intensive industries will intensify NOx emissions with the proportion of secondary industry increasing. When the energy structure is taken as the intermediary variable into the model, the estimated coefficient of agglomeration of energy-intensive industries on NOx in Equation (5) is greater than that in Equation (3), and the coefficient signs of the direct and indirect effects of agglomeration of energy-intensive industries on NOx emissions are different. It seemed that the energy structure showed the masking effect. At this time, agglomeration will benefit the upgrading of energy-saving technologies and the transformation of energy-saving equipment and the large-scale use of new energy fuels, so it greatly reduces the proportion of coal in the energy consumption, thus reducing the 
pollutant emissions [73]. The agglomeration of energy-intensive industries has a positive impact on NOx emissions; however, the agglomeration of energy-intensive industries will reduce this adverse impact by optimizing the energy structure.

Table 6. Research results on the mechanism of NOx emissions by energy-intensive industries agglomeration.

\begin{tabular}{|c|c|c|c|c|c|c|}
\hline \multirow{3}{*}{ Variables } & \multicolumn{3}{|c|}{$\begin{array}{c}\text { The Mediating Variable of } \\
\text { Industrial Structure }\end{array}$} & \multicolumn{3}{|c|}{$\begin{array}{c}\text { The Mediating Variable of } \\
\text { Energy Structure }\end{array}$} \\
\hline & $\ln N E$ & $\operatorname{lnis}$ & $\ln N E$ & $\ln N E$ & lnes & $\ln N E$ \\
\hline & (3) & (4) & (5) & (3) & (4) & (5) \\
\hline \multirow{2}{*}{$\ln N E_{\mathrm{i}, \mathrm{t}-1}$} & $0.6317^{* * *}$ & - & $0.4075^{* * *}$ & $0.6317^{* * *}$ & - & $0.5943^{* * *}$ \\
\hline & $(0.0166)$ & - & $(0.0176)$ & $(0.0166)$ & - & $(0.0193)$ \\
\hline \multirow{2}{*}{$\ln i s_{\mathrm{i}, \mathrm{t}-1}$} & - & $0.8524^{* * *}$ & - & - & - & - \\
\hline & - & $(0.0179)$ & - & - & - & - \\
\hline \multirow{2}{*}{$\ln e s_{\mathrm{i}, \mathrm{t}-1}$} & - & - & - & - & $1.1056^{* * *}$ & - \\
\hline & - & - & - & - & $(0.0212)$ & - \\
\hline $\operatorname{lnhagg}$ & $\begin{array}{c}0.1830^{* * *} \\
(0.0125)\end{array}$ & $\begin{array}{c}0.0067^{* * *} \\
(0.0007)\end{array}$ & $\begin{array}{c}0.1290^{* * *} \\
(0.0157)\end{array}$ & $\begin{array}{c}0.1830^{* * *} \\
(0.0125)\end{array}$ & $\begin{array}{c}-0.0488^{* * *} \\
(0.0053)\end{array}$ & $\begin{array}{c}0.2073^{* * *} \\
(0.0159)\end{array}$ \\
\hline \multirow{2}{*}{$\ln i s$} & - & - & $2.1128^{* * *}$ & - & - & - \\
\hline & - & - & $(0.2156)$ & - & - & - \\
\hline \multirow{2}{*}{$\ln e s$} & - & - & - & - & - & $0.2757^{* * *}$ \\
\hline & - & - & - & - & - & $(0.0785)$ \\
\hline $\ln n u r b$ & $\begin{array}{c}-0.2588^{* * * *} \\
(0.0707)\end{array}$ & $\begin{array}{c}-0.0135^{* * * *} \\
(0.0020)\end{array}$ & $\begin{array}{c}-0.4766^{* * *} \\
(0.0639)\end{array}$ & $\begin{array}{c}-0.2588^{* * *} \\
(0.0707)\end{array}$ & $\begin{array}{c}0.0172 \\
(0.0127)\end{array}$ & $\begin{array}{c}-0.4228^{* * *} \\
(0.0407)\end{array}$ \\
\hline \multirow[t]{2}{*}{$\ln p g d p$} & $-0.4778^{* * *}$ & $-0.0624^{* * *}$ & $-0.6537^{* * *}$ & $-0.4778^{* * *}$ & $-0.0781^{* * *}$ & $-0.5319^{* * *}$ \\
\hline & $(0.0363)$ & $(0.0047)$ & $(0.0377)$ & $(0.0363)$ & (0.0083) & $(0.0430)$ \\
\hline \multirow{2}{*}{$\ln r \& d$} & $0.3947^{* * *}$ & $0.0198^{* * *}$ & $0.4274^{* * *}$ & $0.3947^{* * *}$ & $0.0107^{*}$ & $0.4480^{* * *}$ \\
\hline & $(0.0396)$ & $(0.0056)$ & $(0.0463)$ & $(0.0396)$ & $(0.0065)$ & $(0.0369)$ \\
\hline \multirow{2}{*}{$\ln f d i$} & $0.0635^{* * *}$ & $-0.0135^{* * *}$ & $0.1421^{* * *}$ & $0.0635^{* * *}$ & $0.0252 * * *$ & $0.1360^{* * *}$ \\
\hline & $(0.0123)$ & $(0.0019)$ & $(0.0255)$ & $(0.0123)$ & $(0.0078)$ & $(0.0194)$ \\
\hline \multirow{2}{*}{$\ln e r$} & $-0.3864^{* * *}$ & $-0.0094^{* * *}$ & $-0.4251^{* * *}$ & $-0.3864^{* * *}$ & $-0.0488^{* * *}$ & $-0.4717^{* * * *}$ \\
\hline & $(0.0303)$ & $(0.0024)$ & $(0.0372)$ & $(0.0303)$ & $(0.0087)$ & $(0.0368)$ \\
\hline \multirow{2}{*}{ cons } & $7.4228^{* * *}$ & $1.0860^{* * *}$ & $11.6863^{* * *}$ & $7.4228^{* * *}$ & $0.2498 * *$ & $8.0992 * * *$ \\
\hline & $(0.7617)$ & $(0.0580)$ & $(0.7497)$ & $(0.7617)$ & $(0.0998)$ & $(0.5764)$ \\
\hline \multirow{2}{*}{$\operatorname{AR}(1)$} & -2.044 & -1.7381 & -1.8979 & -2.044 & -3.5169 & -1.9668 \\
\hline & $(0.0409)$ & $(0.0822)$ & $(0.0577)$ & $(0.0409)$ & $(0.0004)$ & $(0.0492)$ \\
\hline \multirow{2}{*}{$\mathrm{AR}(2)$} & 1.2714 & -1.5556 & 1.0735 & 1.2714 & -0.9703 & 1.2362 \\
\hline & $(0.2036)$ & (0.1198) & $(0.2830)$ & $(0.2036)$ & $(0.3319)$ & $(0.2164)$ \\
\hline \multirow{2}{*}{ sargan } & 28.8792 & 26.8120 & 28.2426 & 28.8792 & 23.6664 & 29.3790 \\
\hline & (1.0000) & (1.0000) & (1.0000) & (1.0000) & (1.0000) & (1.0000) \\
\hline
\end{tabular}

Note: * ${ }^{* *}$ and ${ }^{* * *}$ indicate significance at the levels of $10 \%, 5 \%$ and $1 \%$, respectively; the values in parentheses for the variable and constant items represent the standard errors.

From the above, the impact mechanism of new urbanization and agglomeration of energy-intensive industries on NOx through intermediary variables is tested. It is found that the increase of the level of new urbanization not only directly promotes the reduction of NOx but also reduces NOx pollution by improving the energy efficiency and human capital. At present, the high proportion of China's secondary industry is still the key factor, leading to an increase in NOx emissions. Although the agglomeration of energyintensive industries can reduce NOx emissions through the reduction of coal consumption, its masking effect is less than the direct effect of the agglomeration of energy-intensive industries on NOx emissions. Therefore, the total effects of the agglomeration of energyintensive industries on NOx emissions still showed a positive correlation. In order to grasp the inspection results comprehensively, all the inspection results are summarized in Table 7. 
Table 7. Summary of the mechanism analysis.

\begin{tabular}{cccc}
\hline Variables & Object & Type of Effect & $\begin{array}{c}\text { Mediating (Masking) } \\
\text { Effect/The Total Effect }\end{array}$ \\
\hline new urbanization & energy efficiency & mediating effect & 0.1047 \\
energy-intensive industries & mediating effect & 0.0065 \\
agglomeration & industrial structure & mediating effect & 0.0774 \\
\hline
\end{tabular}

\section{Conclusions and Policy Implications}

From the provincial panel data from 2006 to 2017, this paper comprehensively measured and analyzed the impact of the new urbanization and agglomeration of energyintensive industries on NOx emissions in China; at the same time, the systematic GMM method was applied to empirically analyze the impact of China's new urbanization and agglomeration of energy-intensive industries on NOx emissions; what was more, this paper also used the intermediary effect model to explore its impact mechanism.

From above, the conclusions were as follows: (1) There was a negative correlation between new urbanization and NOx emissions. For every $1 \%$ increase in the level of new urbanization, the NOx emissions will be reduced by $0.4766 \%$. There was a positive correlation between the agglomeration of energy-intensive industries and NOx emissions. For every $1 \%$ increase in the agglomeration of energy-intensive industries, NOx emissions will be increased by $0.1290 \%$. (2) The new urbanization and agglomeration of energyintensive industries have a mutual impact on NOx emissions. The agglomeration of energy-intensive industries' promotion of NOx emissions weakens with the increase in the level of new urbanization. (3) From the research results of the transmission mechanism, it showed that the energy efficiency and human capital reflected the intermediary effect mechanism in the impact of new urbanization on NOx. New urbanization reduces the NOx emissions by improving the energy efficiency and human capital. There are two different mechanisms between the agglomeration of energy-intensive industries and NOx emissions such as: the intermediary effect and masking effect. The industrial structure plays an intermediary role in the agglomeration of energy-intensive industries and NOx emissions, while the mechanism of the energy structure in the agglomeration of the energy-intensive industries and NOx emissions is the masking effect.

From the above conclusions, this paper lists the following suggestions: firstly, the emissions reduction effect of new urbanization shall be given attention to, high-level talent agglomeration is supported and the resource factors shall be invested. At the same time, there is no need in excessively pursuing the development speed of new urbanization, ensuring the quality of development, narrowing the economic and social gaps among regions and realizing urban sustainable development. Secondly, it is scientific and reasonable to guide the agglomeration of energy-intensive industries and optimize the industrial structure, as well as the energy structure. Thirdly, it is also significant to improve the level of scientific and technological governance, as well as give full attention to the ability of coordinated emission reduction.

With the energy transformation continuously promoted, carbon emission reduction, carbon emission peak and carbon neutralization have become the focus of global attention. Next, the research will focus on promoting the coordinated treatment of carbon dioxide and air pollution.

Author Contributions: Data curation, Y.Y., and writing-original draft preparation, Y.Y. and T.W. All authors have read and agreed to the published version of the manuscript.

Funding: This study was supported by funds from the First-class Discipline Construction of Beijing University of Chemical Technology (XK1802-5).

Institutional Review Board Statement: Not applicable.

Informed Consent Statement: Not applicable. 
Data Availability Statement: The datasets used and/or analyzed in the current study are available from the corresponding author upon reasonable request.

Conflicts of Interest: The authors declare no conflict of interest.

\section{References}

1. Rodriguez-Alvarez, A. Air pollution and life expectancy in Europe: Does investment in renewable energy matter? Sci. Total Environ. 2021, 792, 148480. [CrossRef]

2. Ścibor, M.; Balcerzak, B.; Galbarczyk, A.; Jasienska, G. Quality of life of patients with bronchial asthma exposed to gaseous air pollution in the place of residence. Sustain. Cities Soc. 2021, 64, 102541. [CrossRef]

3. Kanner, J.; Pollack, A.Z.; Ranasinghe, S.; Stevens, D.R.; Nobles, C.; Rohn, M.C.H.; Sherman, S.; Mendola, P. Chronic exposure to air pollution and risk of mental health disorders complicating pregnancy. Environ. Res. 2021, 196, 110937. [CrossRef] [PubMed]

4. Bakolis, I.; Hammoud, R.; Stewart, R.; Beevers, S.; Dajnak, D.; MacCrimmon, S.; Broadbent, M.; Pritchard, M.; Shiode, N.; Fecht, D.; et al. Mental health consequences of urban air pollution: Prospective population-based longitudinal survey. Soc. Psychiatry Psychiatr. Epidemiol. 2020, 56, 1587-1599. [CrossRef]

5. Gutiérrez-Delgado, R.I.; Barraza-Villarreal, A.; Escamilla-Núñez, M.C.; Hernández-Cadena, L.; Cortez-Lugo, M.; Sly, P.; Romieu, I. Prenatal exposure to VOCs and NOx and lung function in preschoolers. Pediatr. Pulmonol. 2020, 55, 2142-2149. [CrossRef] [PubMed]

6. Ministry of Environmental Protection of the People's Republic of China. Bulletin on the Second National Census of Pollution Sources; Ministry of Environmental Protection of the People's Republic of China: Beijing, China, 2020.

7. Gilbert, B.A.; McDougall, P.P.; Audretsch, D.B. Clusters, knowledge spillovers and new venture performance: An empirical examination. J. Bus. Ventur. 2008, 23, 405-422. [CrossRef]

8. Iammarino, S.; McCann, P. The structure and evolution of industrial clusters: Transactions, technology and knowledge spillovers. Res. Policy 2006, 35, 1018-1036. [CrossRef]

9. Chou, T.L.; Ching, C.H.; Fan, S.-M.; Chang, J.Y. Global linkages, the Chinese high-tech community and industrial cluster development: The semiconductor industry in Wuxi, Jiangsu. Urban Stud. 2011, 48, 3019-3042. [CrossRef]

10. Ehrl, P. Agglomeration economies with consistent productivity estimates. Reg. Sci. Urban Econ. 2013, 43, 751-763. [CrossRef]

11. Lin, X.; Lu, C.; Song, K.; Su, Y.; Lei, Y.; Zhong, L.; Gao, Y. Analysis of coupling coordination variance between urbanization quality and eco-environment pressure: A case study of the west Taiwan strait urban agglomeration, China. Sustainability 2020, 12, 2643. [CrossRef]

12. Borrego, C.; Martins, H.; Tchepel, O.; Salmim, L.; Monteiro, A.; Miranda, A.I. How urban structure can affect city sustainability from an air quality perspective. Environ. Model. Softw. 2006, 21, 461-467. [CrossRef]

13. Li, M.; Huang, Y.; Han, M. How to maintain a sustainable environment? A spatial evolution of urban atmospheric pollution and impact factors in China. Sustainability 2019, 11, 4376. [CrossRef]

14. Han, F.; Lu, X.; Xiao, C.; Chang, M.; Huang, K. Estimation of health effects and economic losses from ambient air pollution in undeveloped areas: Evidence from Guangxi, China. Int. J. Environ. Res. Public Health 2019, 16, 2707. [CrossRef] [PubMed]

15. Poumanyvong, P.; Kaneko, S. Does urbanization lead to less energy use and lower $\mathrm{CO}_{2}$ emissions? A cross-country analysis. Ecol. Econ. 2010, 70, 434-444. [CrossRef]

16. Zhao, Y.; Wang, S.; Zhou, C. Understanding the relation between urbanization and the eco-environment in China's Yangtze River Delta using an improved EKC model and coupling analysis. Sci. Total Environ. 2016, 571, 862-875. [CrossRef]

17. Ge, X.; Zhou, Z.; Zhou, Y.; Ye, X.; Liu, S. A spatial panel data analysis of economic growth, urbanization, and NOx emissions in China. Int. J. Environ. Res. Public Health 2018, 15, 725. [CrossRef] [PubMed]

18. Malthus, T.R. An Essay on the Principle of Population; J. Johnson: London, UK, 1798.

19. Preston, S.H. The effect of population growth on environmental quality. Popul. Res. Policy Rev. 1996, 15, 95-108. [CrossRef]

20. Dietz, T.; Rosa, E.A. Effects of population and affluence on $\mathrm{CO}_{2}$ emissions. Proc. Natl. Acad. Sci. USA 1997, 94, 175-179. [CrossRef]

21. Chalkley, K. Population growth and consumption. Popul. Today 1997, 25, 4. [PubMed]

22. Cramer, J.C.; Cheney, R.P. Lost in the ozone: Population growth and ozone in California. Popul. Environ. 2000, 21, 315-338. [CrossRef]

23. Hosoe, M.; Naito, T. Trans-boundary pollution transmission and regional agglomeration effects. Pap. Reg. Sci. 2006, 85, 99-120. [CrossRef]

24. Li, K.; Chu, C.; Hung, D.; Chang, C.; Li, S. Industrial cluster, network and production value chain: A new framework for industrial development based on specialization and division of labour. Pac. Econ. Rev. 2010, 15, 596-619. [CrossRef]

25. Ehrlich, M.V.; Seidel, T. More similar firms-More similar regions? On the role of firm heterogeneity for agglomeration. Reg. Sci. Urban Econ. 2013, 43, 539-548. [CrossRef]

26. Virkanen, J. Effect of urbanization on metal deposition in the bay of Töölönlahti, Southern Finland. Mar. Pollut. Bull. 1998, 36, 729-738. [CrossRef]

27. Li, X.; Xu, Y.; Yao, X. Effects of industrial agglomeration on haze pollution: A Chinese city-level study. Energy Policy 2021, 148, 111928. [CrossRef]

28. Liu, S.; Zhu, Y.; Du, K. The impact of industrial agglomeration on industrial pollutant emission: Evidence from China under New Normal. Clean Technol. Environ. Policy 2017, 19, 2327-2334. [CrossRef] 
29. Verhoef, E.T.; Nijkamp, P. Externalities in urban sustainability: Environmental versus localization-type agglomeration externalities in a general spatial equilibrium model of a single-sector monocentric industrial city. Ecol. Econ. 2002, 40, 157-179. [CrossRef]

30. Andersson, M.; Lööf, H. Agglomeration and productivity: Evidence from firm-level data. SSRN Electron. J. 2011. [CrossRef]

31. Chen, C.; Sun, Y.; Lan, Q.; Jiang, F. Impacts of industrial agglomeration on pollution and ecological efficiency-A spatial econometric analysis based on a big panel dataset of China's 259 cities. J. Clean. Prod. 2020, 258, 120721. [CrossRef]

32. Shen, N.; Peng, H. Can industrial agglomeration achieve the emission-reduction effect? Socioecon. Plann. Sci. 2021, 75, 100867. [CrossRef]

33. Zhang, L.; Rong, P.; Qin, Y.; Ji, Y. Does Industrial agglomeration mitigate fossil $\mathrm{CO}_{2}$ emissions? An empirical study with spatial panel regression model. Energy Procedia 2018, 152, 731-737. [CrossRef]

34. Gao, C.; Gao, W.; Song, K.; Na, H.; Tian, F.; Zhang, S. Spatial and temporal dynamics of air-pollutant emission inventory of steel industry in China: A bottom-up approach. Resour. Conserv. Recycl. 2019, 143, 184-200. [CrossRef]

35. Ye, P.; Xia, S.; Xiong, Y.; Liu, C.; Li, F.; Liang, J.; Zhang, H. Did an ultra-low emissions policy on coal-fueled thermal power reduce the harmful emissions? Evidence from three typical air pollutants abatement in China. Int. J. Environ. Res. Public Health 2020, 17, 8555. [CrossRef] [PubMed]

36. Zheng, C.; Zhang, H.; Cai, X.; Chen, L.; Liu, M.; Lin, H.; Wang, X. Characteristics of $\mathrm{CO}_{2}$ and atmospheric pollutant emissions from China's cement industry: A life-cycle perspective. J. Clean. Prod. 2021, 282, 124533. [CrossRef]

37. Liu, R.C.; Jiang, F.Y.; Liu, Z.Q. Comments on NOx emission abatement in cement industry. Adv. Mater. Res. 2012, 422, 509-513. [CrossRef]

38. Ialongo, I.; Stepanova, N.; Hakkarainen, J.; Virta, H.; Gritsenko, D. Satellite-based estimates of nitrogen oxide and methane emissions from gas flaring and oil production activities in Sakha Republic, Russia. Atmos. Environ. X 2021, 11, 100114. [CrossRef]

39. Shimada, K.; Mizoguchi, S.; Hibino, G.; Matsuoka, Y. A Study on the Effects on Local Air Quality from the Greenhouse Gas Mitigation Measures. Environ. Syst. Res. 2000, 28, 77-84. [CrossRef]

40. Liu, L.J.; Liang, Q.M. Changes to pollutants and carbon emission multipliers in China 2007-2012: An input-output structural decomposition analysis. J. Environ. Manag. 2017, 203, 76-86. [CrossRef]

41. Hermoso-Orzáez, M.J.; García-Alguacil, M.; Terrados-Cepeda, J.; Brito, P. Measurement of environmental efficiency in the countries of the European Union with the enhanced data envelopment analysis method (DEA) during the period $2005-2012$. Environ. Sci. Pollut. Res. 2020, 27, 15691-15715. [CrossRef]

42. Xu, F.; Shu, C.; Tian, J.; Chen, L. A decade advance in eco-efficiency and cost-benefits of emissions reduction targeting fine chemical manufacturers. J. Environ. Manag. 2021, 298, 113476. [CrossRef]

43. Guo, Y.; Liu, W.; Tian, J.; He, R.; Chen, L. Eco-efficiency assessment of coal-fired combined heat and power plants in Chinese eco-industrial parks. J. Clean. Prod. 2017, 168, 963-972. [CrossRef]

44. Hu, W.; Guo, Y.; Tian, J.; Chen, L. Eco-efficiency of centralized wastewater treatment plants in industrial parks: A slack-based data envelopment analysis. Resour. Conserv. Recycl. 2019, 141, 176-186. [CrossRef]

45. Zhu, Y.; Xia, Y. Industrial agglomeration and environmental pollution: Evidence from China under new urbanization. Energy Environ. 2019, 30, 1010-1026. [CrossRef]

46. Yu, Y.; Deng, Y.R.; Chen, F.F. Impact of population aging and industrial structure on $\mathrm{CO}_{2}$ emissions and emissions trend prediction in China. Atmos. Pollut. Res. 2018, 9, 446-454. [CrossRef]

47. Wang, X.; Luo, Y. Has technological innovation capability addressed environmental pollution from the dual perspective of FDI quantity and quality? Evidence from China. J. Clean. Prod. 2020, 258, 120941. [CrossRef]

48. Yu, Y.; $\mathrm{Xu}, \mathrm{W}$. Impact of FDI and R\&D on China's industrial $\mathrm{CO}_{2}$ emissions reduction and trend prediction. Atmos. Pollut. Res. 2019, 10, 1627-1635. [CrossRef]

49. Ngo, T.Q. How do environmental regulations affect carbon emission and energy efficiency patterns? A provincial-level analysis of Chinese energy-intensive industries. Environ. Sci. Pollut. Res. 2021, 1-17. [CrossRef]

50. Grossman, G.; Krueger, A.B. Environmental impacts of a North American Free Trade Agreement. CEPR Discuss. Pap. 1992, 2, 223-250. [CrossRef]

51. Arellano, M.; Bond, S. Some tests of specification for panel data: Monte Carlo evidence and an application to employment equations. Rev. Econ. Stud. 1991, 58, 277-297. [CrossRef]

52. Blundell, R.; Bond, S. Initial conditions and moment restrictions in dynamic panel data models. J. Econom. 1998, 87, 115-143. [CrossRef]

53. Roodman, D. How to do xtabond2: An introduction to "difference" and "system" GMM in Stata. work. Stata J. 2009, 9, 86-136. [CrossRef]

54. Judd, C.M.; Kenny, D.A. Process analysis: Estimating mediation in treatment evaluations. Eval. Rev. 2016, 5, 602-619. [CrossRef]

55. Baron, R.M.; Kenny, D.A. The Moderator-Mediator variable distinction in social psychological research: Conceptual, strategic, and statistical considerations. J. Pers. Soc. Psychol. 1986, 51, 1173-1182. [CrossRef]

56. Zhao, X.; Lynch, J.G.; Chen, Q. Reconsidering Baron and Kenny: Myths and truths about mediation analysis. J. Consum. Res. 2010, 37, 197-206. [CrossRef]

57. MacKinnon, D.P.; Krull, J.L.; Lockwood, C.M. Equivalence of the mediation, confounding and suppression effect. Prev. Sci. 2000, 1, 173-181. [CrossRef] [PubMed] 
58. Yanna, Z.; Gang, H.; Guisheng, Z.; Keyu, B.; Chaoyu, Y.; Xiangqian, W. Research on coupling coordination and spatial differentiation of new-type urbanization and ecological environment in Wanjiang demonstration area. GeoJournal 2020, 1-13. [CrossRef]

59. Li, W.; Wang, Y.; Xie, S.; Cheng, X. Coupling coordination analysis and spatiotemporal heterogeneity between urbanization and ecosystem health in Chongqing municipality, China. Sci. Total Environ. 2021, 791, 148311. [CrossRef] [PubMed]

60. Liao, S.; Wu, Y.; Wong, S.W.; Shen, L. Provincial perspective analysis on the coordination between urbanization growth and resource environment carrying capacity (RECC) in China. Sci. Total Environ. 2020, 730, 138964. [CrossRef] [PubMed]

61. Fan, W.; Wang, H.; Liu, Y.; Liu, H. Spatio-temporal variation of the coupling relationship between urbanization and air quality: A case study of Shandong Province. J. Clean. Prod. 2020, 272, 122812. [CrossRef]

62. National Bureau of Statistics of China 2007-2018. China Statistical Yearbook; China Statistics Press: Beijing, China, 2018.

63. Ministry of Ecology and Environment of the People's Republic of China 2006-2015. Annual Report on Environmental Statistics; Ministry of Ecology and Environment: Beijing, China, 2015.

64. Ministry of Environmental Protection of the People's Republic of China 2007-2018. China Environment Yearbook; Ministry of Environmental Protection of the People's Republic of China: Beijing, China, 2018.

65. Levin, A.; Lin, C.F.; Chu, C.S.J. Unit root tests in panel data: Asymptotic and finite-sample properties. J. Econom. 2002, 108, 1-24. [CrossRef]

66. Levin, A.; Lin, C.F. Unit root tests in panel data: Asymptotic and finite-sample integrated systems. Econometrica 1992, 61, 783-820.

67. Im, K.S.; Pesaran, M.H.; Shin, Y. Testing for unit roots in heterogeneous panels. J. Econom. 2003, 115, 53-74. [CrossRef]

68. Arellano, M.; Bover, O. Another look at the instrumental variable estimation of error-components models. J. Econom. 1995, 68, 29-51. [CrossRef]

69. Fisher-Vanden, K.; Sue Wing, I. Accounting for quality: Issues with modeling the impact of R\&D on economic growth and carbon emissions in developing economies. Energy Econ. 2008, 30, 2771-2784. [CrossRef]

70. Yu, Y.; Du, Y. Impact of technological innovation on $\mathrm{CO}_{2}$ emissions and emissions trend prediction on 'New Normal' economy in China. Atmos. Pollut. Res. 2019, 10, 152-161. [CrossRef]

71. Pata, U.K.; Caglar, A.E. Investigating the EKC hypothesis with renewable energy consumption, human capital, globalization and trade openness for China: Evidence from augmented ARDL approach with a structural break. Energy. 2021, 216, 119220. [CrossRef]

72. Ahmed, Z.; Asghar, M.M.; Malik, M.N.; Nawaz, K. Moving towards a sustainable environment: The dynamic linkage between natural resources, human capital, urbanization, economic growth, and ecological footprint in China. Resour. Policy 2020, 67, 101677. [CrossRef]

73. Yang, H.Y. A note on the causal relationship between energy and GDP in Taiwan. Energy Econ. 2000, 22, 309-317. [CrossRef] 